\title{
Baśnie w Starej baśni Józefa Ignacego Kraszewskiego
}

\author{
Tales in An Ancient Tale by Józef Ignacy Kraszewski
}

Summary: The author attempts to interpret the best known work of Józef Ignacy Kraszewski, which, although created outside the chronological boundaries of Romanticism, grew out of the ideas and needs of that epoch. The aim of the article is to analyse the genre pattern of An Ancient Tale and to indicate various references to Hindu mythology. The work under discussion combines features of a fairy tale, a historical (archaeological) novel, an epic, a syncretic romantic novel and a legend. The Eastern tradition can be traced not only in the frame story, but also in the names of deities and beliefs.

Key word s: Józef Ignacy Kraszewski, An Ancient Tale, Romanticism, genre syncretism, historical (archaeological) novel, Hindu mythology

Stara baśń..., najbardziej znane dzieło Kraszewskiego, powstało już poza chronologicznymi granicami romantyzmu, bo w roku 1876. Wyrosło jednak $\mathrm{z}$ atmosfery, wyobrażeń i potrzeb tamtej epoki, stając się swego rodzaju summą jej zainteresowań pogańską słowiańszczyzną, prapoczątkami państwa polskiego i związanymi z nimi legendami, którymi zajmowali się najwybitniejsi, by wymienić tylko Juliusza Słowackiego, Zygmunta Krasińskiego i Cypriana Kamila Norwida.

Z romantyzmu wyrastał także niejasny kształt gatunkowy, jaki pisarz nadał swojemu utworowi. Ta niejasność jest uchwytna już w kontraście tytułu: Stara baśń i podtytułu: Powieść z IX w. ${ }^{1}$. Omawiany utwór jest przy tym równocześnie powieścią historyczną (czy też może raczej ,,archeologiczną”) i synkre-

${ }^{1}$ J.I. Kraszewski: Stara baśń. Powieść z IX wieku. Oprac. W. Danek. Wrocław 1975, s. 1. Podkr. - M.S. 
tyczną powieścią romantyczną. Owo skomplikowanie gatunkowe zauważyli oczywiście badacze utworu. Julian Krzyżanowski pisał o powieści Kraszewskiego:

W Starej baśni tedy, słusznie poczytywanej za jedno z dzieł jego najwybitniejszych, dał nie tyle baśń, jak ją sam nazywał, i nie legendę, jak to mówiło się w rozważaniach krytycznych, lecz próbę powieści epickiej $[\ldots]^{2}$.

Charakterystyczne jest owo wahanie uczonego. Zgoda - mamy do czynienia z „próbą powieści epickiej” (jak się wydaje, Krzyżanowski stosuje ten epitet nie po to, żeby wywołać wrażenie tautologii, lecz w sensie wartościującym i chyba w rozumieniu „epopeiczna”, „bliska epopei”), ale też owo użyte określenie „nie tyle” sugeruje, że jednak Stara baśń... jest do pewnego stopnia baśnią lub legendą. Tezę o synkretyzmie gatunkowym utworu wzmacnia Juliusz Kijas, pisząc o krytykach, którzy w dziele Kraszewskiego widzieli „znakomitą powieść historyczną”, podczas gdy „dla innych” była ona „raczej poematem, epopeją w prozie” lub „mistrzowskimi barwami skreśloną legendą, której bohaterem jest cały naród"3. Julian Maślanka zaś nazywa interesujący nas utwór „powieścią-baśnią"4.

Czyli powieść historyczna (archeologiczna), epos prozą (poemat prozą), legenda, wreszcie baśn. Kraszewski przy tym najwyraźniej wymiennie używa w utworze określeń: baśń (s. 436) , bajka (s. 383), podanie (s. 441), powieść (w starym rozumieniu wyrazu - jako synonim opowieści - s. 445), legenda (s. 446) i klechda (s. 317). Dodajmy do tego pieśń i przyśpiewkę, których to nazw gatunkowych nie można odnosić jednak do całości dzieła, lecz jedynie do obecnych w nim lirycznych lub epickich ,wkkładek”. Krzyżanowski dzieli pieśni występujące w utworze na „historyczne” i ,związane [...] z sytuacjami, które śpiew wywołują, zwłaszcza z obrzędami”" O O ile te ostatnie - obrzędowe śpiewy i przyśpiewki - mają charakter liryczny, o tyle śpiewy historyczne są epickie, legendowe, baśniowe. Krzyżanowski wspomina też o baśni Jaruhy o królewnie czarodziejce jako o tekście „wkomponowanym” w Stara baśń... „na zasadzie tej samej, co pieśń"7. Wprowadzone przez badacza rozróżnienie na „pieśń historyczną” i „pieśń obrzędową” jest więc o tyle istotne, że dystans

2 J. Krzyżanow ski: J.I. Kraszewskiego ,historia w powieści”. W: J.I. Kraszew ski: Stara baśń..., s. 16.

3 J. Kijas: Stara baśń Józefa Ignacego Kraszewskiego. Warszawa 1964, s. 68.

${ }^{4}$ J. Maślanka: Literatura a dzieje bajeczne. Warszawa 1984, s. 315.

${ }^{5}$ Utwór cytuję za wydaniem: J.I. Kraszewski: Stara baśń... W nawiasach podaję numery stron.

6 J. Krzyżanowski: Pogłosy literatury ludowej w ,, Starej baśni”. W: Idem: Szkice folklorystyczne. T. 1: Z teorii i dziejów folkloru. Kraków 1980, s. 229.

${ }^{7}$ Ibidem, s. 231. 
dzielący pieśń liryczną od epickiej jest w utworze znacznie większy niż ten, który oddziela pieśn epicką od baśni czy legendy. Na przykład Słowan, który nazywa siebie śpiewakiem lub gęślarzem (s. 54), a wykonywaną przez siebie czynność śpiewaniem, jej wytwór zaś - pieśnia (s. 55), przedstawia właśnie jako pieśń na przykład swoją opowieść o Kraku, smoku i Wandzie (s. 57). Ta legenda została przez Kraszewskiego napisana rytmiczną, czasem rymowaną prozą. Stąd jej charakter - zarazem pieśniowy (co znaczy tu: poetycki), jak również baśniowy czy legendowy. Synkretyzmowi całego utworu (polegającemu na obecności w nim wielu różnych form gatunkowych, ale i na możliwości stosowania wobec niego różnych określeń genologicznych) towarzyszy zatem synkretyzm jego dających się wyodrębnić fragmentów (także pozwalających się rozmaicie klasyfikować gatunkowo).

W ten sam sposób, bez genologicznej pedanterii, przeciwnie, łącząc z sobą gatunki, omawia rzecz sam Kraszewski we wcześniejszym od Starej baśni... dziele Odczyty o cywilizacji w Polsce. Pisze tam, że „Po pieśni [ludowej — M.S.] lub raczej jednocześnie $z$ nią idzie podanie, będące często rozdartym na szmaty śpiewem [...]"8.

Natomiast o legendach dotyczących prapoczątków Polski, a więc o — jak je sam nazywa - dziejach bajecznych (s. 445), pisze tam następująco:

Są to baśnie, powiecie [...].

Nie wiem, czy, jak niektórzy utrzymują, podania te były niegdyś całością poetyczną $[\ldots]$ to pewne, że jest w nich wielkiego poematu osnowa, na który tylko tchu zabrakło późniejszym wieszczom?

Metaforyka rozdzierania pieśni (lub eposu) na poszczególne podania i ponownego tkania $\mathrm{z}$ nich poematu (podania stanowić mają jego osnowę) określa rolę, jaką w tych czynnościach Penelopy wyznaczył sobie sam pisarz. Ma się on stać zbieraczem ,rozdartych na szmaty” pieśni, aby z nich stworzyć nową tkaninę poematu o narodowych prapoczątkach. Także natłok gatunkowych określeń daje się łatwo wyjaśnić, jeśli wziąć pod uwagę cel, jaki przyświecał Kraszewskiemu. Wspomina o tym Wincenty Danek:

Rodowód Starej baśni będzie pełny, jeśli przyjmiemy, że Kraszewski przystąpił do kreślenia opartej na podaniach pierwszych kronikarzy wizji prehistorycznych dziejów Polski z zamiarem stworzenia dzieła, które by mogło zastąpić oryginalne, pochodzące co najmniej ze średniowiecza ludowe pieśni lub epos bohaterski ludowego pochodzenia ${ }^{10}$.

\footnotetext{
8 J.I. Kraszewski: Odczyty o cywilizacji w Polsce. Warszawa 1861, s. 24.

${ }^{9}$ Ibidem, s. 29-30.

${ }^{10}$ W. Danek: Wstęp. W: J.I. Kraszewski: Stara baśń..., s. XXIII.
} 
W ten sposób twórca Starej baśni... wpisywałby się w preromantyczne lub romantyczne dążenia do skomponowania epopei „zastępującej” nieistniejący w danej literaturze epos, który traktuje o mitycznych bądź legendarnych początkach narodu. Tak powstawały szkockie lub czeskie apokryfy, podobny pomysł przyświecał Słowackiemu piszącemu Balladynę, Lillę Wenedę czy Króla-Ducha. Dlatego Kraszewski sięga po swój ulubiony, a w latach siedemdziesiątych XIX wieku także koronny gatunek — powieść, ale równocześnie nadaje jej kształt epopeiczny, nasącza poezją (pieśniami) oraz szpikuje większych i mniejszych rozmiarów wkładkami epickimi (baśniami i legendami).

Nie było to dla pisarza pierwsze takie doświadczenie. Prozatorską próbę tego typu stanowiła powieść Mistrz Twardowski — tekst zbudowany z legend o czarnoksiężniku. Poetycką - Witolorauda, poemat skonstruowany z litewskich „dziejów bajecznych”. Po napisaniu interesującego nas utworu pisarz nie porzuca baśni i w latach osiemdziesiątych tworzy popularny zbiór zatytułowany Bajeczki ${ }^{11}$. Najwyraźniej Stara baśń... była dla niego ważnym, choć przygotowanym już etapem twórczej drogi, najwyraźniej też wyznaczyła dalszy ciąg tej wędrówki. Także oczywiście w „pozabaśniowy” sposób, jako pierwsze ogniwo popularnego cyklu powieści historycznych obejmujących dzieje Polski, złożonego z dwudziestu dziewięciu tomów.

Wróćmy jednak do baśni, którą — nawet wedle Krzyżanowskiego — interesujące nas dzieło w pewnym stopniu jest. A nawet, jak sądzę, w dużym stopniu. Przekonywać może o tym czytelnika sama zastosowana baśniowa rama. Choć początek utworu stanowi zupełnie powieściowy opis poranka w puszczy, to już zakończenie przynosi odniesienie do innej formy literackiej: I ja tam bytem, miód, piwo pitem, bo każda stara baśń tak się przecież kończyć powinna (s. 436).

$\mathrm{Z}$ jednej strony więc baśń $\mathrm{z}$ typowym dla gatunku zakończeniem. $\mathrm{Z}$ drugiej jednak — zakończenie owo zawiera refleksję autotematyczną obnażającą mechanizm ironii romantycznej. Narrator zamyka bowiem tekst tak, jak - zgodnie z posiadaną przezeń świadomością gatunku — zamknąć go powinien. Bo też reprezentujący autora opowiadacz nie jest Słowanem, ludowym poetą bajarzem, ale nowoczesnym twórcą baśni literackiej, świadomym reguł i możliwości gatunku.

Dał on swojemu dziełu konstrukcję szkatułkową — także na wzór baśniowy, tym razem jednak zaczerpnięty nie od rodzimych bajarzy czy kronikarzy, lecz z tradycji Wschodu — z Księgi tysiacca i jednej nocy lub z Księgi papugi. Całość tekstu spina opowieść ramowa, którą tworzy cykl legend wielkopolskich z centralnymi postaciami Popiela i Piasta. Wydarzeniem epopeicznym o przełomo-

${ }^{11}$ Na temat tego zbioru i bajkopisarstwa Kraszewskiego pisze G. Leszczyński: Kraszewski bajkopis. W: Kraszewski. Poeta i światy. Red. T. Budrewicz, E. Ihnatowicz, E. Owczarz. Toruń 2012, s. 251-271. 
wym charakterze jest bowiem dla Kraszewskiego założenie dynastii (i oczywiście koniec dynastii poprzedniej). Dopiero wewnątrz powieści ramowej znajdzie się miejsce dla bohaterów - bajarzy. Krzyżanowski wskazuje w powieści trzy postaci, dzięki którym mogą się w niej pojawić epickie lub liryczne ,wkładki”. To pieśniarz Słowan, „w którego usta włożył [Kraszewski - M.S.] wierszem białym wyrażone Kadłubkowe podanie wawelskie o Krakowie, Wandzie i Kraku bratobójcy oraz zagadkową pieśń o podboju Węgier przez jakiś lud stepowy”'2, a także heroina Dziwa i wiedźma Jaruha, które „reprezentują w powieści poezję ludową w obu jej gatunkach, pieśni i bajki" "13. Ale opowiadaczy jest więcej. Bywa, że jak Sambor wchodzą w tę rolę jednorazowo (s. 51), czasem ledwie wypowiadając kilka zdań, jak Wisz wspominający mit o powstaniu człowieka z kamienia (s. 30). Bywa, że wchodzi w nią narrator główny, wkładając w opowiadaną przez siebie ,starą baśń” jakiś inny wątek baśniowy (np. opowieść o słowiańskim złotym wieku; s. 146-147). Brak natomiast szkatułek wielopoziomowych, a więc sytuacji, kiedy narrator-bohater wprowadza do swojej opowieści kolejnego narratora (wraz z narracją). Tym różni się tekst Kraszewskiego od swoich wschodnich wzorów. Natomiast i bez tej cechy konstrukcyjnie bliżej jest Starej baśni... do Księgi tysiaca i jednej nocy niż do zupełnie inaczej - chronologicznie - uporządkowanych przekazów kronikarskich. Dlatego należałoby mówić nie tyle o baśniowym charakterze całego utworu, a więc o napisaniu go na wzór pojedynczej baśni, ile raczej o cyklu baśni stworzonym wedle wschodnich wzorów.

Najbardziej obszerna i zdecydowanie najważniejsza jest powieść ramowa, która realizuje założenia scottowskiej powieści historycznej (choć umieszczonej w czasach przedhistorycznych). Jej wyjątkowość wśród tylekroć snutych w dawnych i romantycznych czasach opowieści o końcu dynastii Leszków i początkach dynastii Piastów polega zaś na tym, że Kraszewski przyjął w niej zasadę racjonalizacji opowiadanych legend, ponieważ „dzieje bajeczne” „oświetlał [...] ze stanowiska historyka, odejmującego im tradycyjną cudowność". Na przykład zamiast zjedzenia Popiela przez myszy mamy w Starej baśni... pokonanie go przez wojowniczy ród Myszków, czyli Mieszków (s. 311), zamiast „gości zaziemskich” (aniołów) na postrzyżyny Ziemowita przybywają chrześcijańscy misjonarze (s. 252-262), a w miejsce cudownego rozmnożenia potraw w domu Piasta autor ukazuje przyjęcie ,składkowe”, jakie zorganizowali nowo wybranemu kneziowi jego poddani ${ }^{14}$ (s. 269, 381).

Ale wnikliwy czytelnik może też zauważyć, że w narracji ramowej brakuje konsekwencji. Narrator główny ma zwykle świadomość człowieka XIX wieku (np. s. 179), ale czasem bywa mentalnie bliski bohaterom z IX wieku

12 J. Krzyżanowski: Romantyczny historyzm „Starej baśni”. W: Idem: Paralele. Studia porównawcze z pogranicza literatury i folkloru. Warszawa 1977, s. 718.

13 Ibidem, s. 719.

${ }^{14}$ Ibidem, s. 223. Zob. też W. Danek: Wstęp..., s. XXXVII-XXXVIII. 
(np. s. 201-202) ${ }^{15}$. Zwykle posługuje się ,zwyczajną”, nienacechowaną prozą, czasem jednak pobrzmiewa w jego wypowiedziach poetyzacja (rytmizacja) zwłaszcza zaś tam, gdzie streszcza opowiadane przez bohaterów baśnie, a więc w mowie pozornie zależnej (np. s. 51) lub w opisach obrzędów, w których oczywiście ogromną rolę odgrywać będą pieśni (np. s. 119, 161) ${ }^{16}$.

Nie wydaje się to błędem czy przeoczeniem — przeciwnie, można sądzić, że mamy do czynienia z zabiegiem celowym. $Z$ obnażeniem mechanizmu powstawania baśni. Narrator ukazuje bowiem realistycznie skonstruowaną postać i sytuację, na przykład Popiela, ale dzięki kreacyjnej mocy wprowadzonego narratora-bajarza realistyczna postać może wejść w świat cudowności pieśni/ baśni. Tak dzieje się, kiedy Słowan śpiewa kmieciom pieśń o ciągle przecież jeszcze żywym i działającym Popielu:

— Siedzi Chwostek na wieżycy i patrzy z niej wkoło — dobry pan! [...] Siedzi Chwostek, patrzy z dala, kmiecie mrucza, psyli wyja? Śle drużynę: Milczeć cicho lub na gałęź pójdzie licho! Dobry pan! [...] Z Niemcem on się pocałuje, Niemiec dziewkę da mu biała, a wy kmiecie milczeć wara! Bo mu Niemiec da swe miecze i wskroś krnąbrnych wnet wysiecze. Dobry pan!

Wejście w pieśń, a więc w poezję (i w baśń), uruchamia znany choćby z utworów Mickiewicza mechanizm romantyczny. Zgodnie z nim opowiada się legendy (zamiast prawdy) o bohaterze, zwykle o historycznej postaci, żeby stworzyć wzorzec do naśladowania w przyszłości. U źródła tych przedstawień leży literacka, a zarazem historiozoficzna reguła, nazwana przez Ireneusza Opackiego „zasadą opóźnionego działania w historii”, zgodnie z którą

idea, czyn — nie są skuteczne w swoim czasie, w swojej teraźniejszości. [...] skuteczność rozgrywa się w przyszlości dziedziczącej to, co minione. Tu dopiero wieść wpływa na historię, staje się historiotwórcza. I tak naprawdę zaistnieć $\mathrm{w}$ historii — znaczy zaistnieć w przyszłości, w pokoleniach dziedziczących, zaistnieć nie przez skuteczność historiotwórczą, ale historiotwórczą skuteczność wieści o czynie, legendy. [...] W historii można zaistnieć, wchodząc $\mathrm{w}$ nią poprzez legendę — nawet fikcyjną [...]. Wieść historyczna to niekoniecznie wieść o bohaterze, który w historii zaistniał $[\ldots]^{17}$.

\footnotetext{
${ }^{15}$ Zob. też W. Danek: Wstęp..., s. L.

${ }_{16}$ Zob. ibidem, s. LV-LVI.

${ }^{17}$ Wyróżnienia w tekście pochodzą od autora opracowania.
} 
Poezja-testament, poezja-wieść o dawności dla pokoleń przyszłych. Dla jej bohaterów narzędzie utrwalenia, skutecznego upamiętnienia - ale i szansa, dzięki temu, odniesienia ,za grobem zwycięstwa”. Stąd i charakterystyczny bohater tych wierszy: bohater funeralny, Wielki Umarły. Stąd i charakterystyczna sytuacja w wierszach opisywana: moment śmierci, moment pogrzebu - moment przechodzenia z przeszłości żywej w przyszłość legendy, z życia realnego w historyczną wieść-klechdę, z siebie w innych, którzy tę wieść dziedziczą i „biorą w siebie”, stanowiąc o wejściu bohatera $\mathrm{w}$ historię przyszłości ${ }^{18}$.

W wypadku Popiela (który notabene nie jest jeszcze w tym momencie bohaterem umarłym ani nawet umierającym) można by rzeczywiście mówić o legendzie tworzonej z myślą o „wzbudzeniu mściciela”, odniesieniu historycznego „sukcesu”, realizacji „politycznego” celu. Kiedy jednak Jaruha opowiada swoje życie jako baśń o złym zakończeniu (s. 149-151), nie chodzi przecież o „zasadę opóźnionego działania w historii” — przejście realności w baśń wydaje się tu celem samym dla siebie. Ważne, że postać działa niejako na dwóch planach, będąc równocześnie bohaterem realistycznie ukształtowanej historii (w opowieści narratora głównego) i baśni/pieśni (w przekazie narratora-bohatera). Żeby zaś świat realny stał się baśnią/pieśnią, potrzebna jest poezja. Stąd konsekwentna rytmizacja pieśni Słowana, wróżb Dziwy (s. 47-48), śpiewów pogrzebowych (s. 120-121, 124-125) lub weselnych (s. 343-344), a niekonsekwentna $\mathrm{w}$ różnych innych momentach utworu, także w narracji opowieści ramowej. Ta wspomniana już wcześniej niekonsekwencja wydaje się użyta właśnie w celu zamanifestowania momentów „przechodzenia w baśń” lub zbliżania się do jej świata.

Opowieści narratorów-bohaterów służą jednak przede wszystkim innym celom. Najczęściej są to - podobnie jak opowieść ramowa — „dzieje bajeczne". Uzupełniają one narrację ramową o wątki związane z Małopolską i inne „brakujące” opowieści o praprzodkach Polaków. Kolejna pieśń Słowana mówi o rządach dwunastu wojewodów (s. 143-144), opowieść Dobka — o wyścigu, w wyniku którego Leszek został kneziem (s. 314)... Pozostałe dziejowe legendy, których zabrakło w głównej narracji, zamieszczone są w dołączonym do powieści Dopisku. Dziejowych legendach (s. 437-453).

Są jednak w powieści i takie historie, których nie znają kronikarze. Mają one charakter zbliżony do mitu, klasycznej baśni czy apologu.

Najbardziej zagadkowa z nich traktuje o władcy Czytaju, wędrującym ze swoim ludem i przekraczającym zamarznięty Dunaj. Cytowany już Julian Krzyżanowski określa ją jako „zagadkową pieśń, która „,należy bodajże do niejasnej

${ }^{18}$ I. Opacki: Rapsod ostatni, rapsod pierwszy. W: Idem: „W środku niebokręga”. Poezja romantycznych przełomów. Katowice 1995, s. 185-188. Podkr. - M.S. 
grupy podań fabrykowanych przez romantycznych wierszokletów [...] i może kiedyś przypadek pozwoli trafić na jej źródło" ${ }^{19}$. Po co jednak Kraszewski włożył w usta Słowana opowieść o władcy wędrującym w kraje króla dunajskiego (s. 55), kędy dzicy ludzie żyja, roli orać nie umieja, i zwyciężającym dzięki interwencji bogów: Wisznu, a zwłaszcza Samowiły, bo ten ostatni wiatrem smaga i na Dunaj wieje mrozem, a goracem wojsko pali (s. 56)?

Zacznijmy od próby wyjaśnienia, kim jest tajemniczy Samowiła. Wincenty Danek stwierdza w przypisie, że „,nie istniało takie bóstwo w wierzeniach Słowian”, a człon „wiła” oznacza szaleńca ${ }^{20}$. Można by więc założyć, że wymyślone przez pisarza bóstwo odpowiada indyjskiemu Śiwie (Rudra-Śiwa), choćby dlatego, że występuje w Starej baśni... w parze z Wisznu (to para najważniejszych bóstw hinduizmu). Siwa jest przy tym bogiem groźnym, niszczycielem doświadczanym atakami demonicznej furii, zajmuje się pogodą, ma władzę nad skrajnymi postaciami żywiołów (jego wóz, wyobrażający kosmos, jest uruchamiany mocą żaru i mocą zimna; bóstwo ma wreszcie wpływ na wiatr i słońce) ${ }^{21}$. Samowiła, z zaakcentowanym w nazwie szaleństwem, który wieje, mrozi i pali gorącem, ma więc najwyraźniej te same cechy. Inną możliwość interpretacji daje praca Kraszewskiego o mitologii słowiańskiej, będąca omówieniem tez Ignaza Johanna Hanuscha, według którego (i nie tylko według niego) mity słowiańskie mają pochodzenie hinduskie. W zgodzie z przedstawionymi tam XIX-wiecznymi teoriami można Wisznu jako Wayu (personifikację powietrza) utożsamić z mitologicznym litewskim olbrzymem Wieją — stąd, być może, nieco podobnie brzmiąca nazwa Samowiła. W ten sposób można by w pieśni Słowana wyczytać podwojone wezwanie do Wisznu ${ }^{22}$. W każdym razie należy widzieć w pieśni odwołanie do mitologii hinduskiej sugerujące, że Czytaj i jego lud (jak należy się domyślać — praprzodkowie Słowian) przywędrowali z Indii, rozprzestrzeniając swoje wierzenia oraz cywilizacyjne umiejętności.

Egzotyczne i dziwaczne imię bohatera baśni, króla Czytaja, herosa niosącego cywilizację do krain za Dunajem, może z kolei kojarzyć się brzmieniowo z imionami bohaterów staroindyjskich poematów: Sitą, małżonką Ramy, lub królem Czitarathą ${ }^{23}$. Można też szukać innych paraleli we wspomnianym szkicu Kraszewskiego. Wspomina on tam słowiańskie bóstwo o imieniu Sytiwrat

19 J. Krzyżanowski: Pogłosy literatury ludowej w „Starej baśni”..., s. 225.

${ }^{20}$ W. Danek: Przypis. W: J.I. Kraszewski: Stara baśń..., s. 55.

${ }^{21}$ Zob. M. Eliade: Historia wierzeń i idei religijnych. T. 1. Tłum. S. Tokarski. Warszawa 1988, s. 150. Por. M. Jakimowicz-Shah, A. Jakimowicz: Mitologia indyjska. Warszawa 1982, s. $264-265,372$.

${ }^{22}$ J.I. Kraszewski: Mythologia stowiańska i prusko-litewska. W: T. Linkner: W romantycznym kręgu słowiańskich wierzeń. Trentowski-Mickiewicz - Stowacki-Budzyński-Kraszewski. Gdańsk 2014, s. 294, 298, 306.

${ }^{23}$ Zob. W. Erman, E. Tiomkin: Mity starożytnych Indii. [B.tłum.]. Bydgoszcz 1987, s. 93 , 111. 
(Sytiarat) bliskie hinduskiemu pojęciu „Satiawrata”, oznaczającemu ,powrót do życia świata”. Słowiańską nazwę "Sytiwrat” tłumaczy więc Kraszewski jako „Żyti - wrat od życie - wraca, a cząstkę syti- jako żyti lub siti (siać) [...] Sytiwrat mógłby oznaczać powrót do zasiewów, do roli uprawy”. W tym sensie należałoby widzieć Czytaja (w którego imieniu można usłyszeć tę samą cząstkę) jako herosa cywilizacyjnego będącego ludzkim wcieleniem (awatarem) dobroczynnego Wisznu i niosącego życie (siew, sztukę uprawy roli) nieznającym rolnictwa ludom zadunajskim ${ }^{24}$.

Mitotwórczy zabieg Kraszewskiego, łączący słowiańskość z praindoeuropejskością, daje w efekcie tekst mówiący o mitycznych początkach całej słowiańszczyzny, a równocześnie korespondujący z ,nowszymi” historiami założenia Krakowa, Gniezna i dynastii piastowskiej. W ten sposób pisarz tworzy cykl ajtiologiczny, dając mu początek w postaci opowiadania nieopartego najprawdopodobniej na żadnym źródle. Do tego opowiadania właśnie najbardziej pasuje teza Krzyżanowskiego o tym, że Kraszewski wzorem innych romantyków „fabrykował teksty rzekomo archaiczne”, dzięki czemu „Stara baśń otrzymała charakter apokryfu literackiego" ${ }^{25}$.

Znaczący jest przy tym brak w omawianej powieści historii Lecha, Czecha i Rusa (pisarz ledwo wspomina o Lechu w Dopisku..., nie odnosi się jednak ani do jego braci, ani do założenia Gniezna - s. 442). Brak to tym bardziej znaczący, że Długosz, na którego Kraszewski powołuje się w Dopisku..., zaczyna dzieje Polski właśnie od historii książąt braci Lecha i Czecha (Rusa bowiem uznaje za potomka tego pierwszego). Lech jest przede wszystkim założycielem państwa i jego stolicy — Gniezna, które uczynił „siedzibą królewską”, a której etymologię wywodzi kronikarz od wyrazu ,gniazdo, gdyż zrodziło wiele miast polskich, siebie wyjałowiło" ${ }^{26}$. Ta decyzja niemalże przemilczenia Lecha wydaje się uzasadniona, jeśli Kraszewski miał w planach przesunięcie powstania Gniezna do wieku IX i związanie faktu jego założenia z założeniem dynastii piastowskiej, co ma dokumentować pseudoetymologia: Kneźno-Gniezno (s. 416). Równocześnie pisarz włożył w usta Słowana wywód bliski tezie o praindoeuropejskich początkach Słowian i ich wierzeń, dał pra-Polakom mit założycielski i cofnął ich wspólnotową pamięć co najmniej do czasu wędrówki ludów, jeśli nie do znacznie wcześniejszego, do czasu praindoeuropejskiej ekspansji na Europę.

Podobnie jak ten mit, także parabolę Jaruhy o mrówkach, które nie mogą wybrać króla i padają ofiarą ptactwa (s. 317), Krzyżanowski uznaje za - prawdopodobnie - pomysł samego Kraszewskiego ${ }^{27}$. Inaczej osądza badacz opo-

24 J.I. Kraszewski: Mythologia..., s. 308-309.

25 J. Krzyżanowski: Pogłosy literatury ludowej w „,Starej baśni”..., s. 233.

26 J. Długosz: Roczniki, czyli kroniki sławnego Królestwa Polskiego. Ks. 1-2. Tłum. S. Gawęda i inni. Warszawa 2009, s. 96-98, 137-138, 170, 369.

${ }^{27}$ Zob. J. Krzyżanow ski: Pogłosy literatury ludowej w „, Starej baśni”..., s. 230. 
wieść Sambora o skarbach dostępnych tylko w noc Kupały (s. 51), mianowicie identyfikuje ją jako „wariant bajki o palących się pieniądzach, które są dostępne tylko w Niedzielę Palmową (T 8014)"228. W innych miejscach powieści dostrzec możemy zabieg łączenia wątków pieśniowo-baśniowych, a mówiąc dokładniej - aluzyjne włączanie w większą narrację wątków znanych z innej narracji, ale nie na zasadzie wkładek, bo raczej sygnalizujących inny wątek niż rozwijających go w pełni. Na przykład o miejscu pochowania jednego z synów Kraka (a więc i o dokonanej przez jego brata zbrodni) informują, jak w znanej, opartej na ludowym źródle balladzie romantycznej, wyrosłe na grobie ofiary lilie (s. 59), wpisana w opowieść ramową przygoda Znoska, który udaje trupa, by oszukać niedźwiedzia (s. 146), „to bardzo stara bajka Ezopa, spopularyzowana u nas przez Przyjaciót Mickiewicza (T 169)"29, natomiast w innym miejscu jako swoista reinterpretacja powołania Piasta na knezia zostaje wspomniany znany motyw ,z chłopa król” (z kmiecia - kneź - s. 429).

Osobnej refleksji wymaga obszerna baśń Jaruhy o królewnie, która poddaje konkurenta o jej rękę siedmiu kolejnym próbom, odmieniając swą postać czarami, tak aby jej nie mógł poznać - w końcu jednak jest zmuszona mu ulec (s. 363-368). Opowieść tę, pod tytułem O królewnie czarodziejce, Kraszewski włączył także do tomu Bajek dla starych i mlodych dzieci i, jak zapewnia Krzyżanowski, jest ,w systematyce oznaczana jako T 329A, spotykana w folklorze szwedzkim, rumuńskim, siedmiogrodzkim i serbskim" ${ }^{30}$.

Ciekawe, że owa opowieść o królewnie, która nie chce wyjść za mąż, mimo swego poświadczonego tradycją charakteru, wydaje się mocno odbiegać od baśni, do których jesteśmy przyzwyczajeni, w nich bowiem królewny zdecydowanie chcą poślubić księcia i nie wahają się zostać poddane trudnym próbom. Ostateczny zaś ślub odgrywa rolę oczekiwanego happy endu i jest przez bohaterów traktowany jak sukces, a nie jak porażka (oczywiście, inaczej czytalibyśmy tę samą baśń, gdyby jej bohaterem był poddawany próbom książę, a nie królewna czarodziejka).

Jeśliby więc na opowieść Jaruhy spojrzeć przez okulary Brunona Bettelheima, trzeba by stwierdzić, że Kraszewski zaproponował czytelnikom swoistą antybaśń: opowieść nie o rozwoju, lecz o regresji, wskutek której królewna traci dojrzałość, samodzielność i zdolność decydowania o sobie, stając się bezwolną igraszką losu, tego, co komu przeznaczone (s. 398) — w istocie zaś igraszką księcia ${ }^{31}$.

Można więc uznać, że baśnie Kraszewskiego pozostają podwójnie w niezgodzie z przyjętymi obecnie tak powszechnie terapeutycznymi interpretacjami

${ }^{28}$ Ibidem.

${ }^{29}$ Ibidem.

${ }^{30}$ Ibidem, s. 231.

${ }^{31}$ Zob. B. Bettelheim: Cudowne i pożyteczne. O znaczeniach i wartościach baśni. T. 2. Tłum. D. Danek. Warszawa 1985, s. $42-45,52-53,75$. 
Bettelheima. Po pierwsze, niosą sens nie indywidualny, lecz społeczny i religijny, obrzędowy (wiążący się ze społecznością, nie tylko współczesną, lecz także z jej dawnymi dziejami) — zwłaszcza kiedy służą przywoływaniu zbiorowej pamięci (na przykład o wędrówce ludów, która tkwi w świadomości nie tylko Słowana — o czym pisałem wcześniej — i w ogóle Słowian, ale też Niemca Henga - s. 28). Po drugie jednak, wydaje się, że mają szczególny wydźwięk i szczególne oddziaływanie na jednostkę. Mianowicie niejako ubezwłasnowolniają ją, powodują jej regres, wprowadzają ją w rodzaj narkotycznego transu. Do omówionej już bajki o królewnie czarodziejce dodajmy dwa opisy bajania i śpiewania na dworze kniazia Miłosza, którego syna Leszka oślepił okrutny Popiel:

Na grodzie Miłoszowym, pod starymi dębami siedziała matka z Leszkiem, jak dziecko go zabawiają powieściami. Opodal nieco odpoczywat znużony śpiewaniem Stowan, którego dla biednego sprowadzono, aby go pieśniami rozrywat.

Dla Leszka wyszukano żony, stara macierz stała się piastunka dwojga dzieci, czuwajac ciagle nad nimi. Dano mu dziewczę piętnastoletnie, a że ślepota i jego uczynita dziecinnym, bawiło się ich dwoje pod dębami starymi przy matce, jak gdyby zaledwie rozpoczynali życie. Leszkowa żona, która Bietka nazywano, ślepemu swemu, siedzacemu przy niej, śpiewała, on grat na gessli, a matka stara bajki im o bohaterach prawita, i tak dnie schodzity powoli. Ojciec ukryty przystuchiwat się czasem wesolemu gwarowi smutnej pary, nie pokazujac się i nie mieszając do rozmowy, aby słowem jakim nieostrożnym boleści i nieszczęścia nie przypominat.

Baśni i pieśni nie budują w dziele Kraszewskiego osobowości bohaterów, nie podkreślają ich siły sprawczej, możliwości pokonania trudności i wejścia w nową fazę rozwoju, wręcz przeciwnie - hamują działania, tłumią pamięć, relaksują, narkotyzują, usypiają jak kołysanka, wreszcie powodują regres.

Zupełnie inną rolę odgrywają baśni w życiu wspólnoty. Pamiętamy, że mogą one - przeciwnie — pobudzać do czynu, jak pieśń Słowana o Popielu. Przysłuchajmy się teraz jeszcze refleksjom nad nimi głównego narratora, na przykład w następującym opisie heroiny romansu - Dziwy:

Najmłodsza była $w$ domu, najpiękniejsza i najukochańsza, a pieśni najśliczniejsze śpiewała. Matka ja najciekawszych baśni uczyła, ojciec najstarszymi podaniami karmit. Wiedzieli wszyscy, że ja duchy nawiedzaty, że w snach szeptaty jej o tym, o czym nikt, ani ojciec, ani matka, ani siostry nie wiedziały. Kto chciat wiedzieć przyszłość, jej pytat: pomyślała, popa- 
trzała, powiedziała. A pieśni się w niej rodzily tak, jak na wiosnę nad strumieniem kwiaty.

W bardzo podobnie brzmiącym fragmencie narracji, dotyczącym Piasta (s. 104-105), pojawia się jeszcze jeden element współwystępujący z już omówionymi, także o wyraźnie wspólnotowym charakterze. Chodzi o obecne w ustnej tradycji prawo.

Charakterystyczne jest tu jednak nie tylko omówione już bliskie sąsiedztwo baśni, podania i pieśni, ale też ich związek z przeszłością (najstarsze podania Wisza, pieśni Słowana) lub przyszłością (wieszczenia Dziwy — np. s. 194). Należy także dodać wspólnotowy i sakralny charakter baśni/pieśni, uchwytny zarówno w fakcie, że utwory te powstają z natchnienia duchów (przodków?), jak i w swoistym przedstawieniu wykonywania i odbioru „dziejów bajecznych” jako „komunii”:

- Cóż ci to, stary? - zapytat Smerda.

— Obcegom poczul - rzekt trzęsacym głosem Stowan - przed obcym śpiewałem, jakbym miód lat w katużę!

[...] Parę razy, gniewny, odwrócit głowę i oddalit się szybko, dłoniq ucisnawszy struny, aby dźwięku wydać nie śmiaty, usta zacisnąwsy, aby się $z$ nich glos nie dobyt.

s. 61

Kiedy obcy (Niemiec) usłyszał pieśń Słowana, doszło do świętokradztwa, świętość opowieści została skażona. Baśń/pieśń jest bowiem sakramentem, który buduje wspólnotę, łączy ją z sacrum, wyznacza jej cele, przypomina przyszłość oraz informuje o przeszłości. Blisko tu do ujęcia baśni/pieśni jako podobnych do mitu czy rytuału, pozwalających na sakralne budowanie wspólnoty i ucieczkę od teraźniejszości w czas święty (illud tempus) $)^{32}$.

O takiej — zarazem świętej i dwuznacznej — mocy pieśni śpiewa konkurent Słowana Wiłuj:

— Pieśni ty moja, pieśni! Ptaszyno moja złota, tyś jak woda żywota, wskrzeszasz z śmiertelnej pleśni, lecz kto się w nurt twój miota, ten żywot prędko prześni. Dwojaka twoja cnota, żywot i śmierć jest w pieśni. Pieśń zmarlych wskrzesza z grobu, pieśn żywych na śmierć miota, w niej sita światów obu: i śmierci, i żywota!

s. $157-158$

${ }^{32}$ Zob. M. Eliade: Mity wspótczesnego świata. Tłum. K. Kocjan. „Znak” 1988, nr 9, s. 48, 51,54 . 


\section{Bibliografia}

Bettelheim B.: Cudowne i pożyteczne. O znaczeniach i wartościach baśni. T. 2. Tłum. D. Danek. Warszawa 1985.

Danek W.: Przypis. W: J.I. Kraszewski: Stara baśń. Powieść z IX wieku. Oprac. W. Danek. Wrocław 1975.

Danek W.: Wstęp. W: J.I. Kraszewski: Stara baśń. Powieść z IX wieku. Oprac. W. Danek. Wrocław 1975.

Długosz J.: Roczniki, czyli kroniki sławnego Królestwa Polskiego. Ks. 1-2. Tłum. S. Gawęda i inni. Warszawa 2009.

Eliade M.: Historia wierzeń i idei religijnych. T. 1. Tłum. S. Tokarski. Warszawa 1988.

Eliade M.: Mity wspótczesnego świata. Tłum. K. Kocjan. „Znak” 1988, nr 9.

Erman W., Tiomkin E.: Mity starożytnych Indii. [B.tłum]. Bydgoszcz 1987.

Jakimowicz-Shah M., Jakimowicz A.: Mitologia indyjska. Warszawa 1982.

Kijas J.: Stara baśń Józefa Ignacego Kraszewskiego. Warszawa 1964.

Kraszewski J.I.: Mythologia stowiańska i prusko-litewska. W: T. Linkner: W romantycznym kręgu słowiańskich wierzeń. Trentowski-Mickiewicz - Stowacki-Budzyński-Kraszewski. Gdańsk 2014.

Kraszew ski J.I.: Odczyty o cywilizacji w Polsce. Warszawa 1861.

Kraszewski J.I.: Stara baśń. Powieść z IX wieku. Oprac. W. Danek. Wrocław 1975.

Krzyżanow ski J.: Pogłosy literatury ludowej w „Starej baśni”. W: Idem: Szkice folklorystyczne. T. 1: Z teorii i dziejów folkloru. Kraków 1980.

Krzyżanow ski J.: Romantyczny historyzm ,Starej baśni”. W: Idem: Paralele. Studia porównawcze z pogranicza literatury i folkloru. Warszawa 1977.

Krzyżanowski J.: J.I. Kraszewskiego „,historia w powieści”. W: J.I. Kraszewski: Stara baśń. Powieść z IX wieku. Warszawa 1960.

Leszczyński G.: Kraszewski bajkopis. W: Kraszewski. Poeta i światy. Red. T. Budrewicz, E. Ihnatowicz, E. Owczarz. Torun 2012.

Maślanka J.: Literatura a dzieje bajeczne. Warszawa 1984.

Opacki I.: Rapsod ostatni, rapsod pierwszy. W: Idem: „,W środku niebokręa””. Poezja romantycznych przełomów. Katowice 1995. 